\title{
DETERMINANTS OF BANKING CRISIS IN DEVELOPING COUNTRIES
}

\author{
Nguyen Van Phuc, \\ Ho Chi Minh City Open University \\ Luong Duy Quang, \\ Ho Chi Minh City Open University
}

(Received: 04/01/14; Revised: 04/02/14; Accepted: 05/04/14)

\begin{abstract}
This paper identifies determinants associated with probability of banking crisis in developing countries. By using data sample of more than 80 developing countries around the world from 1974 to 2002, the results from our mutivariate logit economitric model indicate that systemic banking crisis tend to erupt as macro-conditions are weak, especially when economies experience low GDP growth and high inflation. Moreover, we also find that the banking sector becomes sensitive to the crisis as the credit growth booming. Besides, other financial macro variables such as high real interest rate and exchange rate are also confirmed to be associated with risk of crisis.
\end{abstract}

Keywords: Banking crisis, financial distress, event method, liquidity, developing countries.

\section{Introduction}

The banking crises that erupted in the US in 2007 are the latest in a series of such episodes that have been experienced by economies in various regions of the world in recent years. In the 1990s, banking crises have occurred in Europe (the 1992-93 crises in the European Monetary System's exchange rate mechanism), Latin America (the middle of 1990s), as well as in East Asia (the 1997-98 crises in Indonesia, Korea, Malaysia, the Philippines, and Thailand). These crises have been costly in varying degrees both in lost output and in the fiscal expense to rescue financial sectors. Through the financial system, their significant spillovers spread internationally and in a number of situations international financial assistance was required to mitigate their severity, costs and spillovers to other countries.

In the wake of these recent crises, the issue of what determinants affecting occurrence of banking crisis has been a hot topic for economists in both developed and developing countries around the world. Accessing this question is quite significant because it does not merely help authorities have confidence for their policies making process but it is also necessary to build up early warning system so that the crisis can be prevented beforehand. However, understanding determinants of banking crisis is not an easy task. Financial 
innovations and the increased integration of global financial markets are driving forces that make us harder to deal with this issue. Such factors push financial system to evolve rapidly and generate new risks for financial systems. One critical thing is that development of financial market seems so complicated and exceeds our knowledge and prediction. What we can do as crisis comes is waiting for crisis wave and witnessing its effects on our life. Thus, widely spreading influence of financial crisis, especially in banking sector, and its possible consequences obviously show important role of studies about determinants of banking crisis. Even though this issue is not new, it always deserves to pursue.

\section{Literature review}

\section{Banking crisis definition}

Effects of banking crisis are always huge and costly to resolve. Therefore, one important thing is that if the collective effects of financial collapse are large enough, the government is forced to intervene. This idea indicates that banking crisis can be defined in terms of behaviors of central banks. In one recent research about financial crisis, Kaminsky and Reinhart (1996) share this idea by specifying two policies of central bank in crisis period. Under this view, banking crisis links closely with two types of events (1) bank runs that lead to the closure, merging, or takeover by the public sector of one or more financial institutions (as in Venezuela in 1993); and (2) if there are no runs, the closure, merging, takeover, or large-scale government assistance of an important financial institution (or group of institutions) that marks the start of a string of similar outcomes for other financial institutions. As discussed by Kaminsky and Reinhart (1996), this approach is not without drawbacks. It could date the crises too late, because the financial problems usually begin well before a bank is finally closed or merged; it could also date the crises too early because the worst of crisis may come later. Moreover, data of banking crisis in terms of their approach is available at limited level.

Given data limitation, this paper, thus, follows definition of banking crisis developed by Caprio and Klingebiel (1996). Accordance with their perspectives, banking crisis is the case in which the net worth of the banking system has been almost or entirely eliminated. This creates something contradiction as banking problem in many nations is still to appear when a banking system has positive net worth. However, Caprio and Klingebiel (1996) indicate that the problem would be much easier if definition of banking crisis above linked with insolvency of banking system. More obviously, that is, bad loans are strong enough to "blow out" system's capital. Based on data of banking sector in developing countries during 1980s, Caprio and Klingebiel (1996) suggest that nonperforming loans must account for at least 5 percent of total loans so that loan loss would be sufficient to wipe out a banking system.

\section{Banking crisis theory}

In the recent years, a number of theories have been developed around the world to provide insight view as well as explain logic behind crisis trouble in the banking sector. Most of studies have based on basic roles of the banking system in an economy to explain crisis phenomena. For instance, in many studies such as Diamond and Dybvig (1983), Demirguc-Kunt and Detragrache (1998), these authors agree that one of important roles of the banking system are financial intermediaries whose responsibility is to provide liquidity for the real economy. The bank system serves 
its intermediary role by mobilizing shortterm deposits from savers and lending that money, usually in long-term loans, to borrowers. As value of bank's asset does not match value of liabilities, the bank gets into trouble. In a different way, a banking crisis could be understood through misbalance between value of liabilities and assets on banks' balance accounts. Here, one question arises is that in what conditions, or more obviously what determinants will lead to such mismatch in a banking system? In order to find out the answer, a number of theories have been developed and suggest hundreds of determinants for further studies. Generally, these determinants could be classified into three groups as follow.

\section{Macroeconomic group}

Determinants belong to this group including cyclical output downturn, terms of trade deterioration, inflation. As stated by Demirguc-Kunt and Detragrache (1998), cyclical output downturn is clearly related to risk of crisis. An output downturn reflects adverse macroeconomic shocks that will deteriorate banks' balance sheet through higher rates of non-performing loans. Therefore, the probability of a banking crisis is expected to be high as economy experience low growth GDP. In another research about banking crisis, English (1996) argue that baking sector problems could follow after successful stabilization in countries with a history of high inflation. As shown by English (1996), the financial sector tends to be overblown as yearly increasing inflation by time. An anti-inflationary program could be applied to cool down the economy. In such case, banks see one of their main sources of revenue disappear, and banking problems may follow. Another indicator that could deteriorate banks' balance sheet is terms of trade. Kaminsky and Reinhart (1996) point that a yearly declination of terms of trade of 10 percent could trigger crises. This is because adverse terms of trade would drive down purchasing power and may lead to the weakness in imports in period before the crisis

\section{Financial group}

Financial liberalization, interest rate policy, tightened monetary policy, exchange rate are good representativeness to this group. As mentioned previously, banking crisis could be understood through misbalance between value of liabilities and assets on banks' balance accounts. Bank balance sheets should deteriorate because banks typically collect shortterm deposits to fund long-term projects. When interest rates in lending contracts are fixed, an increase in interest rates will quickly be reflected in the cost of (shortrun) deposits, whereas it will take more time to pass on the increase in the cost of funds to borrowers. Moreover, negative effect of high short-term interest rate probably passes to borrowers as the banks are requiring higher lending rate. In such case, borrowers' balance sheet should be deteriorated, and non-performing loans increase. Therefore, short-term interest rate could be good indicators to predict probability of banking crisis. In reality, a surge of interest rate may come from various ways such as tightened monetary policies (Ergungor and Thomson, 2005), or financial liberalization (Gabis, 1993), or fight against speculative attack (Kaminsky and Reinhart, 1996, Sach et al 1996). Moreover, several studies also suggest that exchange rate belongs to this group. A sudden withdrawal of foreign deposits after a long period inflow is recognized as source of bank sector instability. Demirguc-Kunt and Detragrache (1998), as cited by Khamis (1996), capital inflows increase is due to the combination effect of two driving forces, i.e liberalization and high domestic rate. As foreign investors 
lost confidence or international interest rate increase, foreign depositors withdraw their deposit. As result of this, domestic banks become illiquid.

Demirguc-Kunt and Detragrache (1998) also consider foreign deposit risk is likely a determinant that makes bank's balance sheet get worse. As banks borrow foreign currency for domestic loans, a sharp devaluation of exchange rate threatens bank profitability. In this case, banks eliminate exchange rate risk by following dominantly domestic deposits. However, there is no hope that the risk disappears completely because foreign exchange rate risk is transferred to borrowers. Unpredicted depreciation of domestic currency can deteriorate borrowers' profit, and thus, affect banks' balance sheet through an increase of bad loans.

\section{Institutional group}

Demirguc-Kunt and Detragrache (1998) agree that a trigger of banking crisis may come from a shock of information. As cited by Diamond and Dybvig (1983), selffulfilling may cause bank run if depositors realize the deterioration in quality of banks' assets. Running on one bank should not lead to bank crisis, but in some conditions, depositors cannot discriminate healthy banks with weak one. Bank run turns into bank panic. Demirguc-Kunt and Detragrache (1998), therefore, argue that deposit insurance declines the risk of bank panic. However, its correlation with banking crisis is still under controversy, as Kane (1989) has shown, the presence of deposit insurance usually come with moral hazard phenomenon that create strong incentive for the banks taking on more risk. In the countries following financial liberalization and deposit insurance policies, occurrence of baking crisis's probability tend to be double because liberalization creates good conditions for taking on more risk. Besides, a strong system of bank supervision is acknowledged as a critical determinant that mitigates risk as well as damage of banking crisis. Ergungor and Thomson (2005) indicate that bank supervisor's task is to supervise and maintain healthy banking system, but this purpose is not always fulfilled. In some situations, budgetary and staffing constraints are main barriers limiting their control ability. Another frequently mentioned reason influencing quality control of banking supervisor is political pressure, especially under booming periods of an economy. For instance, as financial liberalization come with promoting economic growth. The bank supervisor is not quite easy to close insolvent bank and regulate the bank pursuing highly risky projects because these projects are usually profitable. Such reasons make bank supervision system get worse and trigger eruption of banking crisis.

\section{Research method}

\section{Model choice}

Review of empirical works has opened two alternatives to reach the second objective of this study, identifying threshold value of each variable which minimizies banking crisis occurrence. The first method is signal-noise ratio. As noted earlier, minimization of signal-noise ratio by replacement of different threshold allows Kaminsky and Reinhart (1996) to limit frequency of crisis. Even though this approach does not fulfill completely the second objective (marginal effect of each variable on probability of crisis are not issued), its result is relatively acceptable (banking crisis occurrence minimization). Perhaps the best approach is multivariate logit model. This model provides background for estimation of marginal effect of each variable on crisis occurrence so that probability of crisis can be reduced. 
Moreover, the logit model receives a great support from econometric software such as Sata, Eviews, ect. Therefore, data analysis process is always shortened in few minute even dataset contains thousands of observation. For reasons discussed above, multivariate logic model is employed to access research questions. In accordance with Gujarati (2003), logit model is based on logistic distribution function. The model can be formulated mathematically as follow:

$P_{i}=E\left(Y=1 / X_{i}\right)=\frac{1}{1+e^{-\left(\beta_{1}+\beta_{2} X_{i}+\ldots+\beta_{k} X_{k}+U\right)}}$

We rewrite formulation above as

$$
\begin{aligned}
& P_{i}=\frac{1}{1+e^{-Z}}=\frac{e^{z}}{1+e^{z}} \\
& L_{i}=\mathbf{h}\left(\frac{P_{i}}{1-P_{i}}\right)=Z_{i}=\beta_{1}+\beta_{2} X_{2}+\ldots+\beta_{k} X_{k}+U_{j}
\end{aligned}
$$

$\mathrm{Pi} /(1-\mathrm{Pi})$ is the odds ratio in favor of banking crisis appearance the ratio of the probability that one observation will experience banking crisis to the probability that it will not experience banking crisis. If
Where: $\mathrm{Zi}=\beta 1+\beta 2 \mathrm{X} 2+\ldots+\beta 3 \mathrm{X} 3+\mathrm{Ui}$

It is not quite difficult to verify that as $\mathrm{Zi}$ ranges $-\infty$ to $+\infty$, then $\mathrm{Pi}$ ranges between 0 and 1 and Pi nonlinearly relate to Zi. Supposed that probability of banking crisis occurrence is $\mathrm{Pi}$, then probability of tranquility state (1-Pi) is

$$
1-P_{1}=\frac{1}{1+e^{i}}
$$

So, we can write

$$
\frac{P_{i}}{1-P_{i}}=\frac{1+e^{Z}}{1-e^{-Z}}=e^{Z}
$$

$$
\begin{aligned}
& L_{i}=\operatorname{Ln}\left(\frac{P_{i}}{1-P_{i}}\right)=\alpha_{1}+\beta_{1} \text { Growth }+\beta_{2} \text { Realint erest }+\beta_{3} \text { Ex }+\beta_{4} \text { Inflation }+\beta_{5} \text { TOT }+\beta_{6} M 2 / \text { Re serve } \\
& +\beta_{7} \text { Deposit }+\beta_{8} \text { Creditgrowth }+U_{i}
\end{aligned}
$$

Where Growth is vector of growth factors, Real interest is vector of interest rate factor, Ex is vector of exchange rate factors, Inflation is vector of inflation factors, TOT is vector of terms of trade factors, M2/Reserve is vector of speculative attack factors. Deposit is vector of deposit insurance factors. Credit growth is vector of liberalization factors, and ui is vector of summarizing unobservable factors that contribute to risk of crisis. we take the natural log of (3.1), we obtain:

Based on banking crisis theory and data availability, our specification model is suggested as follows

\footnotetext{
${ }^{1}$ The electronic version of the banking crisis database is available at http://www1.worldbank.org/finance/html/database_sfd.html or http://www.luclaeven.com/Data.htm

\section{Data source}

The most updated database of Caprio-Klingebiel (1996) about systemic banking crisis presented by Honohan et al $(2005)^{1}$ is the main source to obtain data for banking crisis variable. This paper presents a database on the timing of systemic banking crises and policy responses to resolve them. It tracks series of systemic banking crises for the period 1974-2002, with specific information on 
policy respond of over 40 banking crisis around the world.

Demirgüç-Kunt et al (2006), and International association of deposit insurance (2008) are mainly data source for deposit insurance dummy variable while the rest variables such as inflation, growth rate, terms of trade (TOT), and so on are collected from IMF's dataset, International Financial Statistic (IFS). IFS has been published monthly since January 1948. In 1961, the monthly was supplemented by a yearbook, and in 1991 and 2000, respectively, IFS was introduced on CD-ROM and the Internet.

\section{Results and discussion}

As stated by Demirguc-Kunt and Detragrache (1998), banking crisis is a special variable. This is due to that it could generate its "feedback" effects on remaining explanatory variables. An illustration of this is the credit to GDP ratio. This ratio tends to decline after onset of banking crisis, and a decrease of credit will pull down other variables such as GDP. Such effects must puzzle our model when we would like to observe how independent each variable contributes to risk of crisis. To deal with problem, we run two regression equations with two different samples on banking crisis. In the equation 1 , full duration of banking crisis must be identified, and then, our regression model includes all observations that following end date of crisis. In the equation 2, all observations after the first year of crisis will be eliminated. An advantage of this technique is that it allows us to prevent puzzle effects of crisis variable on explanatory variables, but it will reduce considerably dataset for our analysis. The final conclusion depends on the comparison between two regression results.

Table. Regression results of banking crisis determinants

\begin{tabular}{|c|c|c|c|}
\hline Variables' Name & Expected sign & Regression 1 & Regression 2 \\
\hline Growth & - & -0.030078 & $-0.046952 *$ \\
\hline TOT & - & $2.48 \mathrm{E}-14 * *$ & $3.34 \mathrm{E}-14 * * *$ \\
\hline Exchange & + & $0.000260 * * *$ & 0.000122 \\
\hline Realinterest & + & $0.024467 * * *$ & $0.027087 * *$ \\
\hline Inflation & + & $0.024370 * * *$ & $0.028599 * * *$ \\
\hline M2/Reserve & + & 0.000352 & $9.63 \mathrm{E}-05$ \\
\hline Credit Growth & + & $1.32 \mathrm{E}-07$ & $3.52 \mathrm{E}-07 * *$ \\
\hline Deposit & Ambiguous & $0.551795 * * *$ & 0.214369 \\
\hline $\mathbf{C}$ & & $-2.083688 * * *$ & $-3.502206 * * *$ \\
\hline Log likelihood & & -468.4443 & -165.168 \\
\hline Number of crisis & & 184 & 43 \\
\hline $\begin{array}{r}\text { Number of } \\
\text { observations }\end{array}$ & & 1104 & 976 \\
\hline LR statistic $(8 \mathrm{df})$ & & 57.95049 & 22.25593 \\
\hline $\begin{array}{r}\text { Probability } \\
\text { (LR stat) } \\
\end{array}$ & & 1.17E-09 & 0.004463 \\
\hline McFadden R-squared & & 0.058251 & 0.063121 \\
\hline \multicolumn{4}{|c|}{$\begin{array}{l}\text { One, two, and three asterisks show significance levels of } 10 \%, 5 \% \text {, and } 1 \% \text {. } \\
\text { Regression 1: panel eliminating observations following end year of crisis } \\
\text { Regression 2: panel eliminating observations after the first year of crisis }\end{array}$} \\
\hline
\end{tabular}


The effect of macro variables on risk of crisis

As predicted in theory, both real interest rate and inflation have statistical significance in all specifications and get expected sign. This confirms that the banking system in developing countries turns to be unstable as economy experiences nominal and real interest rate shocks. Besides, there is also evidence that low GDP growth is highly associated with probability of banking crisis, confirming hypothesis that development of the real side of economy link closely to onset of banking crisis in the period 1974 to 2002. These findings are equivalent with results in many previous studies such as Demirguc-Kunt and Detragrache (1998), Hagen and Ho (2003), and Hardy and Pazarbasioglu (1998).

Another factor influencing the occurrence of banking crisis is exchange rate. Information in regression 1 indicates a depreciation of exchange rate influences on likelihood of banking sector crisis in many developing countries. However, several studies such as Demirguc-Kunt and Detragrache (1998), Hagen and Ho (2003) provide a contradictory conclusion to our finding. The different results probably come from many reasons such as types of sample, data analysis method, so on. Moreover, as mentioned by Fahrettin (2001), exchange rate regime could be classified by various types including independent floating, managed floating, crawling bands, crawling pegs, pegged within bands, fixed peg arrangements, currency board arrangements. Through various channels, each type has unique effects on banking stability. Thus, under this view, we believed that further research is necessary to provide insight view about relationship between exchange rate regimes and banking crisis before making any conclusion.

\section{The effect of financial variables}

$\mathrm{M} 2 /$ reserve is statistically insignificant in both two speculations, rejecting hypothesis that a flee currency leads to banking crisis. This finding totally differs from what mentioned in research of Demirguc-Kunt and Detragrache (1998). Possibly, the difference originates from types of sample. Demirguc-Kunt and Detragrache (1998) use sample of developing and developed countries while our study focus on 80 developing countries. According to Calvo and Reinhart (2000), lack of credibility and limited access to international markets, high liability dollarization, and higher pass through from exchange rate to inflation are the key factors that make developing countries harder to follow flexible exchange rate regime that could double their debt's obligation or pegged exchange regime that creates incentives for speculators earning profit. In the other words, developing countries' choice should move to somewhere in the middle of the range. This will reduce risks from speculative attacks when speculators feel more difficult to devaluate exchange rate. Therefore, it is not surprising as our finding is different from those of Demirguc-Kunt and Detragrache, in the case our sample just concentrates on developing countries where speculative intention is hard to come true.

Unlike M2/reserve, Credit Growth tends to show unclear trend in both specifications. Significance level of its coefficient does not get necessary threshold in regression 1 , but it turns to be very statistically significant at 
regression 2 (p-value $<1 \%$ ). Does this mean that there is not enough evidence to confirm relationship between credit booming and banking crisis? In one research about banker's behavior in crisis period, Ergungor and Thomson (2005) have provided an excellent theory to explain this phenomenon. Under their view, occurrence of banking crisis usually comes from a long period of expansionary monetary policy with low interest rate. Such policies normally lead to excessive monetary growth that increases in value of assets such as real estate, shocks, and consumer loans. In this case, banks respond rationally to these changes by increasing their market share to these markets because increasing price of assets raise a good signal that return of investment on the market is rising while risk is falling. This tendency continues until everyone believes that the asset prices will continue to grow. However, as discussed by Ergungor and Thomson (2005), a long period of rising asset prices and booming credit is probably causing highly inflationary economy that creates strong incentive for the governments to intervene. In this situation, higher interest rate and restriction on loan policies are introduced to cool down the economy. As a consequence, unexpected scenarios are triggered later on such as economic growth slows down, depressing asset prices, lowering borrowers' ability to pay, increasing loan defaults, and eventually eroding banks' capital. One interesting point in Ergungor and Thomson's theory is that credit growth just plays important role in pre-crisis period and contributes to risk of crisis is very limited in postcrisis period. This argument shapes well to findings of the paper as credit growth's coefficient does not get necessary p-value in regression 1 (equation eliminating observations following end year of crisis), but statistically significant at regression 2 (equation eliminating observations after the first year of crisis).

\section{The effect of institutional variables}

Perhaps the most interesting determinant is deposit insurance dummy variable which shows contradictory results in both two specifications. Statistical evidences coming from regression result 1 supports hypothesis that deposit insurance appears to facilitate moral hazard phenomenon spreading. This brings us an idea that no deposit protection or implicit scheme of deposit insurance would be more effective from perspective of minimizing frequency of banking crisis occurrence. However, what we have seen in regression 2 leads us to treat this argument with a caution. No evidence about effect of deposit insurance dummy variables on banking crisis is found. Significance level of this variable is lowest one despite strongly statistical evidences in previous specification model. Therefore, the authors' perspective is that any conclusion about the likelihood of deposit insurance on banking sector fragility is not confident and further investigation is required. Actually, these findings are not a novelty because real effect of deposit insurance on banking sector is still under controversy among economists. Demirguc-Kunt and Detragrache (2002) find that crises are more likely in countries with a deposit insurance system is in place while Hagen and Ho (2003) do not recognize any persuasive result in their research. This is not quite difficult to explain this contradiction as authors tend to use different ways to approach 
crisis problems in the banking sector. For example, Hagen and Ho (2003) use money market pressure definition to access banking crisis problems, but DemirgucKunt and Detragrache (1998) apply a group of 4 criteria $^{2}$ to determine whether crisis occur or not. Different approaches, of course, lead to different results. Moreover, there are still a lot questions needed to figure out such as how much insurance threshold is to keep banking system stable or what is role of banking supervision, information transparency in the financial system, and so on.

\section{Conclusion}

The main purpose of this research is to investigate determinants of banking crisis in developing countries. Applying multivariate logit model in sample of 80 developing countries, the author finds that banking crisis is more likely to erupt as macro-conditions are weak, especially when an economy experience low GDP growth and high inflation. Moreover, other macro and financial variables such as exchange rate, credit growth are good indicators to explain mechanism of banking crisis. These findings have been confirmed by many previous studies such as Demirguc-Kunt and Detragrache (1998), Hagen and Ho (2003), and Hardy and Pazarbasioglu (1998).

Our findings in this research are very useful for developing countries' government, particularly in designing anti-inflationary policies. As mentioned, anti-inflationary policies tend to increase real interest rate in inflationary period. On one hand, this policy is very helpful to cool down the economy, but on the other hand, it gradually puts more burdens on the banking system. In other words, in a long term, anti-inflationary policies just move risk of crisis around, not reduce it. Hence, anti-inflationary policies should be designed carefully, particular in balancing between effectiveness and a cost of possible banking crisis.

\footnotetext{
2 Demirguc-Kunt and Detragrache (1998) use 4 criteria to define occurrence of banking crisis involving (1) The ratio of non-performing assets to total assets in the banking system exceeded 10 percent, (2) The cost of the rescue operation was at least 2 percent of GDP, (3) Banking sector problems resulted in a large-scale nationalization of banks,(4)Extensive bank runs took place or emergency measures such as deposit freezes, prolonged bank holidays, or generalized deposit guarantees were enacted by the government in response to the Crisis.
} 


\section{REFERENCES}

Caprio, G. \& Klingebiel, D., 1999/2003, Episodes of Systemic and Borderline Financial Crises. [online]. Available at www.banking.mfpa.ru/files/dataset_01.pdf [accessed june 16 2009].

Caprio, G. \& Klingebiel, D., 1996, Bank Insolvency: Bad Luck, Bad Policy, or Bad Banking?. [online]. Available at www.siteresources.worldbank.org/DEC/ Resources/18701_bad_luck.pdf [accessed june 16 2009].

Calvo, G., A. and Reinhart, G., 2000, "Fear of Floating”, mimeo, University of Maryland Demirgüç-Kunt, A. \& Detragiache, E., 1998, The Determinants of Banking Crises in Developing and Developed Countries, IMF staff paper, 45, pp. 81-109.

Demirgüç-Kunt, Asli, Edward J. Kane, and Luc Laeven, 2006, Determinants of DepositInsurance Adoption and Design, Journal of Financial Intermediation, Elsevier, vol. 17(3), pages 407-438. Available at www2.bc.edu/ kaneeb/DI\%20Adoption.06. pdf, [Accessed Aug 27 2009].

Diamond, D.,W., \& Dybvig, P., H., 1983, Bank Run, Deposit insurance, and Liquidity, Journal of Political Economy, University of Chicago Press, vol. 91(3), pages 40119. Available at www.minneapolisfed.org/Research/qr/qr2412.pdf, [accessed May 20 2009]

Ergungor, O., E., \& Thomson, J.,B., 2005, Systemic Banking Crises, Policies discussion papers of Federal Reserve Bank Of Cleveland. Available at www.clevelandfed. org/research/POLICYDIS/No9Jan05.pdf, accessed on 04 Aug, 2009.

English W., 1996, Inflation and financial sector size, Journal of Monetary Economics, Volume 44, Issue 3

Galbis, V., 1995, Financial sector Reforms in Eight Countries: Issues and Results, IMF Working Paper No. 95/141. Available at www.papers.ssrn.com/sol3/papers. cfm?abstract_id=883287 [accessed July 25 2009].

Garcia, Gillian, G., H., 1999, Deposit insurance : A survey of Actual and Best Practices, IMF Working Paper No. 99/54. Available at www.imf.org/external/pubs/ft/ wp/1999/wp9954.pdf, [accessed Aug 25 2009].

Giannetti, M., 2006, Financial Liberalization and Banking Crises: The Role of Capital Inflows and Lack of Transparency, Journal of Financial Intermediation, Volume 16, Issue 1, pp. 32-63. Available at www.ssrn.com/abstract=869388, [accessed Aug 04 2009].

Gujarati, D., N., 2003, Basic Econometrics, 4th ed, United States: Gary Burke.

Hardy, Daniel and Ceyla Pazarbasioglu, 1998, "Leading Indicators of Banking Crises:

Was Asia Different?” IMF Working Paper no. WP/98/91.

Honohan, Patrick \& Laeven, L., 2005, Systemic Financial Distress: Containment and Resolution, Cambridge, UK: Cambridge University Press.

Fahrettin Y., 2001, Choice Of Exchange Rate Regimes For Developing Countries, Africa Region Working Paper Series No.16

Kaminsky, G., \& Reinhart, C., 1996, The Twin Crises: The Causes of Banking and Balance-of-Payments Problems, International Finance Discussion Papers 544, Board of Governors of the Federal Reserve System (U.S.). Available at www. 
home.gwu.edu/ graciela/HOME-PAGE/...WORK/.../twin-crises.pdf [accessed on July 06 2009].

Kane, E., J., 1989, The S\&L Insurance Mess: How Did it Happen?, Washington, D.C.: Urban Institute Press.

Khamis, M., 1996, Credit and Exchange Rate-Based Stabilization, IMF Working Paper, Vol., pp.1-54. Available at www.papers.ssrn.com/sol3/papers.cfm?abstract id=882951 [accessed June 18 2009].

Kyei, A., 1995, Deposit Protection Arrangements: A Survey, IMF Working Paper, no. 134. Available at www.papers.ssrn.com/sol3/papers.cfm?abstract_id $=883280$ [accessed June 30 2009].

Sachs, Jeffrey D., Aaron Tomell, and Andres Velasco, 1996, Financial Crises in Emerging Markets: The Lessons From 1995, Brookings Papers on Economic Activity: 1, Brookings Institution, pp. 147-215. 